\title{
Backlash and State Strategies in International Investment Law
}

\author{
Malcolm Langford, ${ }^{*}$ Daniel Behn ${ }^{* *} \&$ Ole Kristian Fauchald ${ }^{* * *}$
}

June 1, 2017

\begin{abstract}
The development of the modern investment treaty regime represents a remarkable extension of international law in the post-war period. However, the development of this regime has precipitated a backlash from some states, various civil society actors, and scholars over the past decade. For all intents and purposes, it appears that the central (underlying) reason for the backlash is one right: the procedural right granted to foreign investors allowing them to bring claims directly against the state hosting their investment. Many of these investment treaty arbitrations (ITAs) have resulted in sizable compensation awards for actions that many states believe are both legitimate and within their exclusive purview as sovereigns. This tension between the rights afforded to private foreign investors under international treaties and the legitimate rights of sovereign states to regulate in the public interest of their domestic citizenry has culminated in efforts by states to weaken the regime. This chapter examines the strategies and tactics that states are employing to scale back the unintended consequences of the international investment regime while simultaneously claiming adherence to its international legal obligations.
\end{abstract}

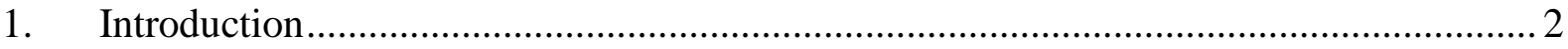

2. Strategic and tactical choices ................................................................................. 4

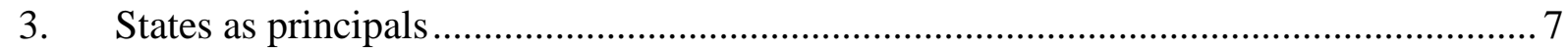

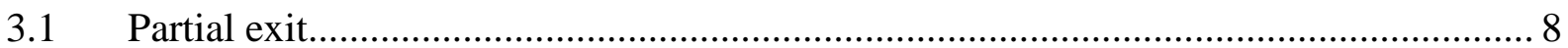

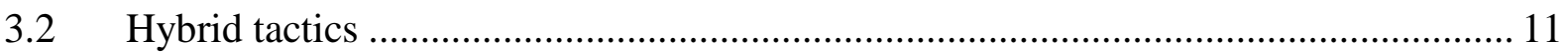

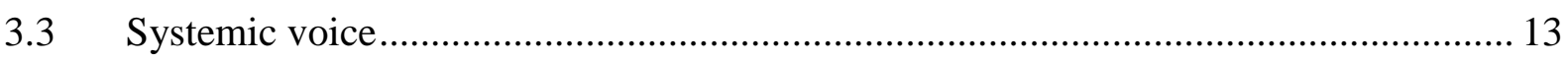

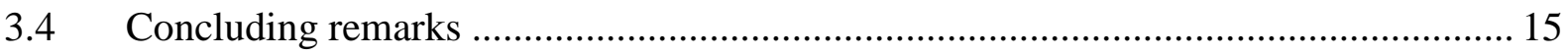

4. States as litigants in investment treaty arbitration ...................................................... 15

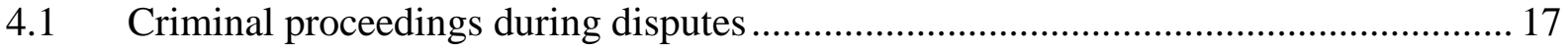

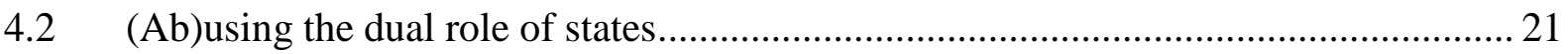

4.3 Refusing to enforce or satisfy arbitral awards .......................................................... 23

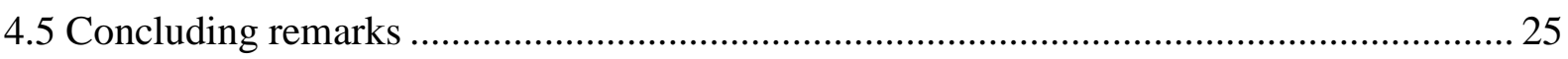

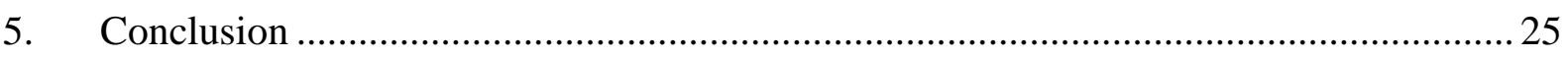

\footnotetext{
* Professor of Law, University of Oslo and Co-Director, Centre on Law and Social Transformation, University of Bergen and CMI. Email: malcolm.langford@jus.uio.no.

** Postdoctoral Researcher, PluriCourts Centre of Excellence, University of Oslo. Email: d.f.behn@jus.uio.no. Special thanks to research assistant, Maxim Usynin, for his valuable assistance with the research for section 4.

*** Professor of Law, PluriCourts Centre of Excellence, University of Oslo. Email: o.k.fauchald@jus.uio.no.
} 


\section{Introduction}

The development of the modern investment treaty regime is emblematic of the post-Second World War period in international law. With the ever increasing 'legalization of world politics', international legal institutions have shifted structurally from a classic model of coexistence to an international law of cooperation. ${ }^{1}$ This structural shift is exemplified by a number of key features such as the expansion of treaty law, the multiplication of actors subject to international law and the emergence of novel adjudicatory mechanisms for resolving international legal disputes. Such legalization of global affairs has also precipitated a backlash from some states claiming that the proliferation of international law is undercutting national sovereignty and marginalizing the political maneuverability of states at the international level.

All of these features are apparent in the international treaty regulation of foreign investment. Largely built on a network of more than 3500 bilateral investment treaties (BITs) and regional free trade agreements (FTAs), ${ }^{2}$ a handful of plurilateral investment treaties, ${ }^{3}$ as well as customary international law, ${ }^{4}$ foreign investors are granted beneficiary rights aimed at the post-establishment protection of their investments. It has been claimed that "no other category of private individuals" is "given such expansive rights in international law as are private actors investing across borders". 5

These developments, like other areas of international law, were viewed in teleological terms: an ever-expanding pattern of treaties and custom that, even if fragmented, would increasingly constrain domestic sovereignty for the greater good of global governance. Success was thus defined as the "victory of the supra- or multi-national over the parochial national". ${ }^{6}$ Yet, this assumption of path dependency and evolutionary progress is risky. While the rules and institutions determined by politics are 'stickier' than those determined in economic markets, ${ }^{7}$ they can shift decidedly over time in the reverse direction. If political contestation was present during the formation of any institution or rule, it is not axiomatic that it will disappear afterwards. Moreover, even when such seminal political contestation was not present, a

\footnotetext{
${ }^{1}$ Thomas Gammeltoft-Hansen and Tanja Aalberts, 'Politics in the age of international law', in Thomas Gammeltoft-Hansen and Tanja Aalberts (eds.), Changing Practices of International Law (Cambridge University Press, 2017).

${ }^{2}$ UNCTAD provides an extensive database on international investment agreements, http://investmentpolicyhub. unctad.org/IIA (accessed 16 May 2017).

${ }^{3}$ Such treaties include the Energy Charter Treaty (ECT), chapter 11 of the North American Free Trade Agreement (NAFTA) and the Association of South-East Asian Nations (ASEAN) Comprehensive Investment Agreement.

${ }^{4}$ Patrick Dumberry, 'Are BITs Representing the 'New' Customary International Law in International Investment Law?’ (2010) 28(4) Penn State International Law Review 675-701.

${ }^{5}$ Beth Simmons, 'Bargaining over BITS, Arbitrating Awards: The Regime for Protection and Promotion of International Investment' (2014) 66 World Politics 12-46, at 42.

${ }^{6}$ Jose Alvarez, 'The Return of the State' (2011) 20 Minnesota Journal of International Law 223-264, at 223.

${ }^{7}$ Paul Pierson, 'Increasing Returns, Path Dependence, and the Study of Politics' (2000) 94 American Political Science Review 251-267.
} 
regime's trajectory or external developments may engender new forms of political contestation.

In this respect, we should not be surprised that some states have reasserted themselves in their role as treaty-makers and overall regime shapers. Commonly referred to as a legitimacy crisis, ${ }^{8}$ the international investment regime is under attack, with even some prominent 'insiders' expressing disquiet. ${ }^{9}$ Primarily, however, this phenomenon is not solely about the expansiveness of the substantive rights granted to foreign investors under international investment agreements (IIAs), but rather the combination of such rights with the robustness of their investor-state dispute settlement (ISDS) provisions and the increasing number and range of states subject to disputes. With over 850 known investment treaty arbitrations (ITAs) initiated to date, ${ }^{10}$ as well as an unknown number of instances in which the threat of ITA has been used as a bargaining tool, states hosting foreign investors are increasingly finding themselves having to defend their domestic laws and policies before and in the shadow of international arbitral tribunals.

For all intents and purposes, it appears that a key element of the backlash, in the sense that a backlash would not have occurred without the existence of the remedial right granted to foreign investors (a private individual or corporation). Claims can be directly brought by them against the state hosting their investment. The resulting litigation has resulted in sizable compensation awards for actions that many states believe are both legitimate and within their exclusive purview as sovereigns. ${ }^{11}$ This tension between the rights afforded to foreign investors under IIAs and the legitimate rights of sovereign states to regulate in the public interest of their domestic citizenry has arguably resulted in a single overarching strategy being employed by certain states dissatisfied with the international investment regime. The tactics vary dramatically but the strategy is the reassertion of sovereign control by limiting legally or effectively the international legal rights granted to foreign investors. As we shall see, this

\footnotetext{
${ }^{8}$ Michael Waibel, Asha Kaushal, Kyo-Hwa Chung \& Claire Balchin (eds), The Backlash Against Investment Arbitration: Perceptions and Reality (Hague: Kluwer Law, 2010); for an overview, see Malcolm Langford, 'Cosmopolitan Competition: The Case of International Investment' in Cecilia Bailliet \& Katja Aas (eds), Cosmpolitanism Justice and Its Discontents (New York: Routledge, 2011), 178.

${ }^{9}$ See, inter alia, contributions in Jean Kalicki and Anna Joubin-Bret (eds), Reshaping the Investor-State Dispute Settlement System: Journeys for the 21st Century (Hague: Brill, 2015); and Roberto Echandi \& Pierre Sauvé (eds), Prospects in International Investment Law and Policy (Cambridge: Cambridge University Press, 2013).

${ }^{10}$ PluriCourts Investment Treaty Arbitration Database (PITAD), https://jus-pitad01.uio.no/ (accessed 16 May 2017). Not all ITAs are public, and many awards remain confidential. Awards that are public are made available at: http://www.italaw.com (accessed 16 May 2017). Currently, approximately 20\% of ITA awards are not in the public domain.

${ }^{11}$ See, inter alia, David Collins, 'Loss Aversion Bias or Fear of Missing Out: A Behavioural Economics Analysis of Compensation in Investor-State Dispute Settlement' (2016) Journal of International Dispute Settlement 1-23. See also Daniel Behn, 'Legitimacy, Evolution, and Growth in Investment Treaty Arbitration: An Empirical Evaluation of Recent Decisions' (2015) 46(2) Georgetown Journal of International Law 363-415 at 373-375.
} 
strategy is almost always employed by states that have been subject to at least one dispute; ${ }^{12}$ and has been termed the 'return of the state' in the international investment regime. ${ }^{13}$

For those states dissatisfied with the practice of the international investment regime, the strategic importance in reasserting sovereign control over this area of international law is justified by claims that ITA over the last decade has been lop-sided, biased against states and constitutes an unacceptable delegation of sovereign authority and control to international adjudicators. ${ }^{14}$ However, the precise reasons for the backlash vary amongst states and there are competing explanations. There is arguably a complex set of instrumental calculations, intrinsic beliefs and background factors that drive state behavior in this field. While there are no states that have achieved a complete exit from the international investment regime, there are a number that have sought to make significant changes to their practice in order to address perceived or real gaps and imbalances. However, only a minority have launched a vocal and existential attack on the investment regime. The majority have sought to implement changes in order to maximize sovereign maneuverability while simultaneously adhering to international law, mirroring the form of state behavior under study in this book. As the editors state the, "multiplication of legal regimes, overlapping jurisdictions, and diffusion of authority”, of which the international investment is emblematic, “opens up an increased room for political manoeuvring in relation to international law". ${ }^{15}$

This chapter examines how states are shaping their critical responses to an international legal order. How do they seek to reassert control while simultaneously remaining part of the international investment regime and enjoying its potential economic benefits? The chapter proceeds as follows. Section 2 sets out an analytical framework in order to categorize distinct strategic and tactical choices made by states in reaction to a backlash against the current regime. Section 3 examines what tactics states as principals are using to scale back the rights granted to foreign investors in IIAs; and section 4 analyses tactics states are using as litigants when defending and justifying their actions in ITA.

\section{Strategic and tactical choices}

On one hand, there appears to be a single overarching strategy that is being employed by select states in response to the current international investment regime: to reassert sovereign

\footnotetext{
${ }^{12}$ Lauge Poulsen \& Emma Aisbett, 'When the Claim Hits: Bilateral Investment Treaties and Bounded Rational Learning' (2013) 65(2) World Politics 273-313; but compare with: Wolfgang Alschner, 'The Impact of Investment Arbitration on Investment Treaty Design: Myth Versus Reality' (2017) 42 Yale Journal of International Law, where the author finds that the incidence of ITA claims do not in and of themselves trigger changes in IIA design.

${ }^{13}$ Alvarez, supra $n 5$.

${ }^{14}$ Daniel Behn, Tarald Berge \& Malcolm Langford, 'Poor States or Poor Governance: Explaining Outcomes in Investment Treaty Arbitration’ (2017 forthcoming) Northwestern Journal of International Law \& Business.

${ }^{15}$ Thomas Gammeltoft-Hansen and Tanja Aalberts, 'Politics in the age of international law', in Thomas Gammeltoft-Hansen and Tanja Aalberts (eds.), Changing Practices of International Law (Cambridge University Press, 2017), p. *.
} 
control by maximizing sovereign maneuverability, increase the policy space of states to regulate in the public interest without running afoul of IIA obligations, and reduce potential liability in ITAs brought by aggrieved foreign investors. On the other hand, multiple tactics have been adopted to achieve this strategy and the strategy itself is perhaps best viewed along a spectrum, from stronger to weaker approaches.

The tactics range from the well-known to the novel and emerging and fall within two categories: (i) the state as principal - i.e., treaty-maker and international regime shaper; and (ii) the state as litigant in ITA. ${ }^{16}$ The relevant tactics that states have as principals include, inter alia: imposing moratoriums on the signing of new IIAs; refraining from ratifying signed IIAs; publicly critiquing the regime; adjusting negotiating strategies over new IIAs (including development of model IIAs and increased use of impact assessments and policy coordination during negotiations); excluding ISDS from some IIAs; calling for the renegotiation of IIAs already in force; terminating of IIAs; and withdrawing from arbitration institutions (in particular, $\operatorname{ICSID}^{17}$ ).

The tactics used by states as litigants in disputes include, inter alia: attempting to bind adjudicators to sovereignty protecting interpretations of certain treaty provisions; commencing domestic criminal proceedings against foreign investor claimants after a dispute arises; refusing to comply with awards; engaging in delay tactics; increasing the use of procedural motions for challenging arbitrators; requesting security for costs and other forms of injunctive relief; and making novel challenges to the jurisdiction of tribunals.

It is important to distinguish between the scope and intensity of the strategy along a spectrum. While a number of states have sought exit, the majority have sought to remain a part of the broader international legal order while at the same time reducing the breadth of its international legal obligations. Thus, tactics employed by some states may be weak and not intended to engender significant reform. Rather they involve subtle and discrete acts that amount to a tweaking of, or partial expression of discontent with, the regime. However, some tactics are particularly strong. The state may take a systemic approach (e.g., seek to terminate some treaties or engage in constant non-compliance) or make radical departures from the spirit of the regime (e.g., drastically curtailing foreign investor protections or harassing foreign investors with domestic criminal complaints).

Figure 1 melds this principal/litigant and strong/weak strategic dichotomy in order to group the relationships of states to the current regime (i.e., that which has emerged since the early 2000s). ${ }^{18}$ States that deploy strong tactics as both principals and litigants can be characterized

\footnotetext{
${ }^{16}$ Anthea Roberts also discusses the dual role as treaty parties and respondents in 'Power and Persuasion in Investment Treaty Interpretation: The Dual Role of States' (2010) 104(2) American Journal of International Law $179,180$.

${ }^{17}$ International Centre for Settlement of Investment Disputes.

${ }^{18}$ Modern IIAs emerged from Europe in the years following the Second World War. However, it was not until the 1990s that the majority of the 3000 plus IIAs were signed. We delimit the current regime from the early 2000s for the reason that this is when ITAs (as based on IIAs) began to be filed with increasing frequency.
} 
as absolute opponents as reflecting their total opposition to the regime (group I). States that strongly seek reform but largely play by the rules of fair litigation can be labelled principled opponents: they wish to change the framework but largely abide by previous commitments (group II). States that largely support the regime but seek to obstruct proceedings when subject to ITA through strong-form litigation tactics can be labelled reluctant compliers (group III). Finally, there is a diverse group of states that adopt neither set of tactics, which we will call compliers (group IV). By compliers we mean states that actively or passively evince a formal commitment to the idea and practice of the regime. However, this group may contain false positives (states that move easily into another group once the costs of compliance become too high).

The functions of these tactics differ. Their activation may carry different material or symbolic effects for the international investment regime, with some tactics potentially precipitating both types of effects. ${ }^{19}$ The regime may be materially affected in a systemic fashion if the space in which arbitrators operate in future disputes is curtailed, or specifically if states attempt to obstruct or block individual arbitral disputes to which they are a party. Primarily, tactics with material and systematic effects will aim at revising, restricting, reforming or terminating the IIAs that grant arbitrators the authority to effectively adjudicate claims.

\section{Figure 1: Mapping state tactics}

Principal tactics

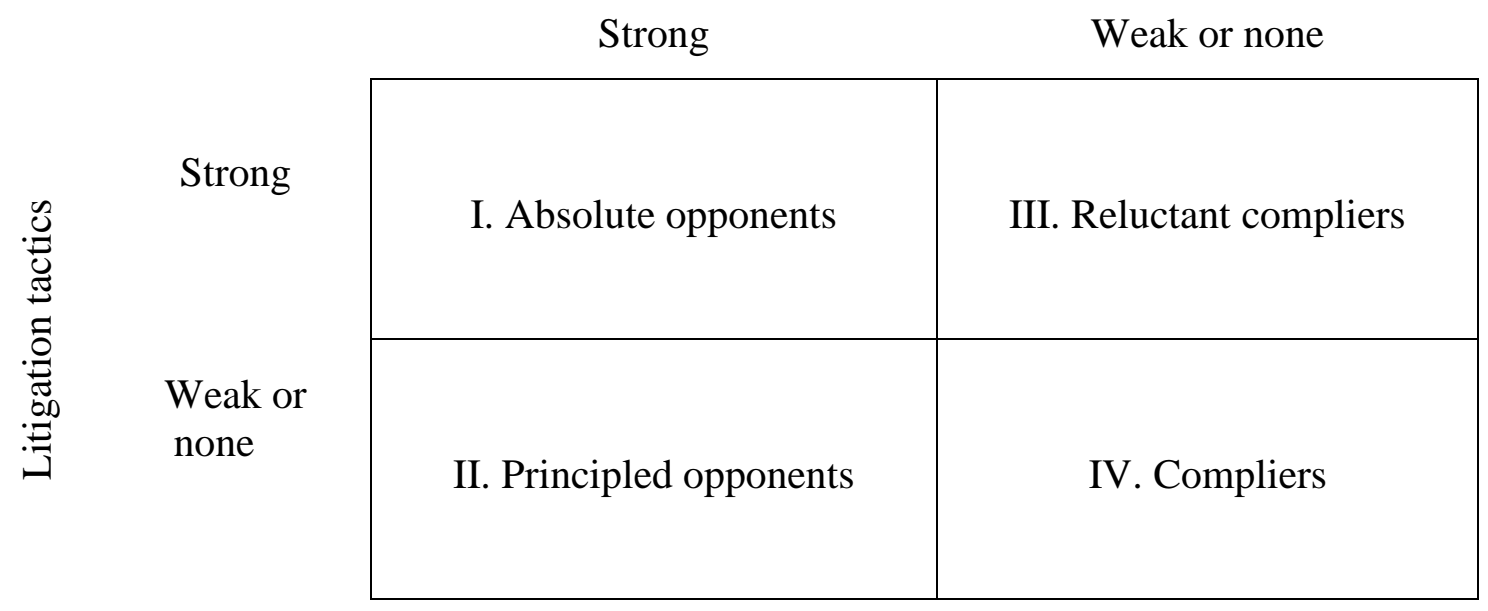

Tactics employed by states and other stakeholders may have symbolic effects if they send a signal to arbitrators about state displeasure with the operation of the regime, which might result in arbitrators being more cautious or deferential in ruling against states. ${ }^{20}$ These

\footnotetext{
${ }^{19}$ On this general distinction, see César Rodriguez-Garavito, 'Beyond the Courtroom: The Impact of Judicial Activism on Socioeconomic Rights in Latin America' (2011) 89 Texas Law Review 1669-1698 at 1679-1681; on the symbolic and communicative effect of law generally, see Thomas Meisenhelder, 'Law as Symbolic Action: Kenneth Burke's Sociology of Law' (1981) 4 Symbolic Interaction 43-57.

${ }^{20}$ However, if these tactics by states are seen as overtly abusive or in violation of general principles of law, arbitrators may actually become less deferential. For a theory and test of arbitrator reflexivity, see Malcolm
} 
symbolic effects might result from state criticism of the regime or partial exit but also indirectly through the use of various litigation tactics, which collectively might shift arbitrator behavior towards a more deferential mode of adjudication. For a small number of particularly vocal states opposed to the regime, the symbolic effects may also indirectly influence the behavior of other states. For instance, while many states perceive themselves as compliers (group IV) their practices of treaty-making and litigation may be influenced by more vocal states, and they may consequently be classified otherwise.

\section{States as principals}

In the literature on the international investment regime, state tactics as 'principals' have been divided into exit and voice. ${ }^{21}$ Exit involves a break with the regime while the use of voice seeks regime reform. These tactics can vary significantly in nature and strength. As illustrated in figure 2 below, they range from full system exit (i.e., systemic termination of all treaties with no intent to renegotiate) through to minor modifications to treaty texts.

\section{Figure 2: Principal tactics}

\begin{tabular}{|c|c|c|}
\hline & $\begin{array}{c}\text { Strong } \\
\text { (absolute or principled opponents) }\end{array}$ & $\begin{array}{c}\text { Weak } \\
\text { (reluctant compliers or compliers) }\end{array}$ \\
\hline Exit & $\begin{array}{l}\text { Systemic termination of treaties } \\
\text { Termination of ISDS provisions } \\
\text { Refraining from ratifying signed } \\
\text { treaties }\end{array}$ & $\begin{array}{l}\text { Sporadic termination of treaties } \\
\text { Sporadic termination of ISDS } \\
\text { provisions } \\
\text { Sporadic refusal to ratify signed treaties }\end{array}$ \\
\hline Voice & $\begin{array}{l}\text { Withdrawal from ICSID } \\
\text { Attempting forced treaty renegotiation } \\
\text { Systemic political delegitimisation } \\
\text { New model treaties }\end{array}$ & $\begin{array}{l}\text { Sporadic treaty renegotiation } \\
\text { Sporadic clarifications of treaties } \\
\text { Sporadic adoption of new models }\end{array}$ \\
\hline
\end{tabular}

Langford \& Daniel Behn, 'Managing Backlash: The Evolving Investment Treaty Arbitrator', (2017 forthcoming) European Journal of International Law (pre-published version).

${ }^{21}$ Roberts supra n 15; Alvarez supra n 5; Nancy Welsh, Andrea Kupfer Schneider \& Kathryn Rimpfel, 'Using the Theories of Exit Voice , Loyalty, and Procedural Justice to Reconceptualize Brazil's Rejection of Bilateral Investment Treaties' (2014) 45 Washington Universtity Jorunal of Law and Policy 105-143;. On the general distinction between exit and voice, see Albert Hirschman, Exit, Voice, and Loyalty: Responses to Decline in Firms, Organizations, and States (Cambridge: Harvard University Press, 1970), 4. 
From the perspective of this volume, full exit is not a tactic of particular interest. In such a scenario, states would transparently relinquish their commitment to the regime and could not be accused of seeking to reform or undermine their existing commitments. However, while announced exits have grabbed headlines, there is no example to date of any states conducting a full exit from the international investment regime. ${ }^{22}$ The reasons for this will be explored below. Moreover, a number of states have employed a combination of partial exit and partial voice tactics simultaneously, although their intentions for such a combination are not always clear. We can therefore classify tentatively three types of strong tactics by states which have been used and are likely to impact the regime: (i) partial exit; (ii) hybrid tactics; and (iii) systemic voice.

However, it is worth noting that not all states share the overarching strategy of limiting the protections granted to foreign investors under existing and future treaties. The tactics are not unidirectional. A few states, such as China and Germany, have sought to expand the rights of foreign investors under future IIAs. ${ }^{23}$ Moreover, most states continue to sign new IIAs (particularly through FTAs) although their support may be for a less potent regime.

\subsection{Partial exit}

The first category is partial exit and is exemplified by announced attempts by a cluster of Latin American states to leave the regime. Yet, these strident proclamations of exit provide a certain puzzle. States such as Bolivia, Venezuela, Ecuador and Argentina have terminated some of their bilateral investment treaties (BITs) and/or exited or announced an exit from the ICSID Convention (also known as the Washington Convention); ${ }^{24}$ but they are far from executing a full exit from the international investment regime. ${ }^{25}$ It might be thought that these states are being duplicitous - seeking to remain within the international investment regime (in order to capture its benefits) while weakening their own obligations. However, it seems that the partial exit of these states might be better characterized as unintended. They genuinely

\footnotetext{
${ }^{22}$ However, a few Latin American states are getting close. Both Ecuador and Bolivia have terminated a number of their IIAs with no intent to renegotiate them; and both of these states have denounced the ICSID Convention.

${ }^{23}$ Kate Hadley, 'Do China's BITS matter? Assessing the Effect of China's Investment Agreements on Foreign Direct Investment Flows, Investor's Rights, and the Rule of Law' (2013) 45 Georgetown Journal of International Law 255-321, at 275-309; Chester Brown, Commentaries on Selected Model Investment Treaties (Oxford: Oxford University Press, 2013), 7.

${ }^{24}$ Bolivia, Ecuador, and Venezuela withdrew from the ICSID Convention in 2007, 2010 and 2012, respectively. At one point, Argentina also signaled its intention to follow suit and the Government introduced a bill in its parliament in March 2012 to this effect. Federico Lavopa, Lucas Barreiros \& Victoria Bruno, 'How to Kill a BIT and not Die Trying: Legal and Political Challenges of Denouncing or Renegotiating Bilateral Investmewnt Treaties' (2013) 17 Journal of International Economic Law 869-891 at 871.

${ }^{25}$ Clint Peinhardt \& Rachel Wellhausen, 'Withdrawing from Investment Treaties but Protecting Investment' (2016) 7(2) Global Policy 571-576, 'documents the group of states that have taken advantage of unilateral withdrawal, and demonstrate that states can recalibrate their international legal commitments without eschewing contemporary international investment law'. While this might be correct at the aggregate level, our updated numbers show that a small but growing number of states might be classified as absolute opponents to the regime.
} 
thought they could fully exit. Instead, they discovered that the legal infrastructure of the regime makes the regime sticky. ${ }^{26}$

The two principal forms of exit are termination of IIAs and withdrawal from procedural commitments to particular arbitration forums, e.g., through denunciation of the ICSID Convention. The first wave of states initially embraced the latter approach. ${ }^{27}$ This 'Latin American' strategy was completely precipitated by investment-related disputes that culminated in ITAs - mostly through the ICSID procedure. ${ }^{28}$ However, the effectiveness of this ICSID Convention exit strategy has been questioned. The ICSID Convention is procedural not substantive in orientation. ${ }^{29}$ Frequently, an ISDS provision in an IIA will include a number of institutional and non-institutional options for claim initiation (of which ICSID arbitration is just one option). Obviously, withdrawal from the ICSID Convention does not imply withdrawal from other venues for ITA. Moreover, withdrawal from the ICSID Convention would not prevent foreign investors from bringing cases under the ISCID Additional Facility rules. ${ }^{30}$ Thus, to date, the impact of ICSID Convention withdrawal has been more symbolic than material.

Where there is lack of mutual agreement among states as to termination, the stickiness of the international investment regime depends on the challenges of unilaterally terminating the individual IIA. Various lock-in provisions extend the horizon of investment protections well into the future. First, most treaties include 'tacit' renewal clauses, a feature somewhat peculiar to IIAs. These clauses usually provide for automatic renewal of the IIA for a new fixed period (frequently for a subsequent period of 10 years). Any unilateral termination of these agreements would have no effect on foreign investors' rights unless the IIA includes a separate termination clause. Second, even once termination is achieved, states may face 'survival clauses'. Most IIAs include a 'tail' that provides treaty protections for foreign

\footnotetext{
${ }^{26}$ One challenging issue that arises when the parties to an IIA mutually agree to terminate the treaty arises in relation to foreign investors' interests. To what extent are their rights protected in such situations? This remains a largely unresolved issue in international law. On the one hand, it can be argued that states are free to eliminate the effects of a treaty if they are in mutual agreement. On the other hand, it can possibly be argued that states are not free to do so if it would detrimentally affect essential rights and expectations of third parties. Whether it could be argued that IIAs provide rights to investors that would be protected according to this latter argument is debatable. Tania Voon, Andrew Mitchell \& James Munro, 'Parting Ways: The Impact of Investor Rights on Mutual Termination of Investment Treaties' (2014) 29(2) ICSID Review - Foreign Investment Law Journal 451473.

${ }^{27}$ Our arbitration PITAD database (supra n 9) reveals the following number of disputes filed per state: Bolivia (15), Venezuela (43) and Ecuador (24). The majority are ICSID arbitrations (62\% or 51 out of 82 ITAs).

${ }^{28}$ See Malcolm Langford \& Daniel Behn, 'Managing Backlash: The Evolving Investment Treaty Arbitrator', (2017 forthcoming) European Journal of International Law (pre-published version).

${ }^{29}$ See Lavopa, Barreiros \& Bruno supra n 23, at 874-878.

${ }^{30}$ An effective unilateral withdrawal from the ISDS provisions of IIAs would require termination of the IIA or renegotiation of the IIA with ISDS provisions excluded. Moreover, it is not clear when, and sometimes even if, the denunciation of ICSID takes effect. There is dispute in the literature over whether consent is required from parties to different bilateral treaties (since it affects the possibility of access to dispute resolution) and whether ICSID continues to apply to 'survival' clauses in treaties. See discussion in Lavopa, Barreiros \& Bruno supra n 23 , at 877-878.
} 
investors (who made their investment prior to the termination of the treaty) for an extended period after the treaty terminates. One study found that such provisions prolong investor protections for an average of 12.5 years after treaty termination in order to provide a predictable legal environment. ${ }^{31}$ The stickiness of IIAs is further enhanced by the bilateral character of most of these treaties. Such IIAs are frequently signed as a token of friendly relations. It is likely that a decision to unilaterally terminate an IIA with all or particular states could be perceived as unnecessarily unfriendly. Nevertheless, many states, including those that have withdrawn from the ICSID Convention, have also unilaterally or through mutual consent terminated some of their IIAs. Most IIAs have termination clauses allowing for one state party to the treaty to unilaterally give notice of the intent to not renew a treaty for an extended period as stipulated in the treaty. This automatic renewal is typically subject to provisions that allow for either state party to unilaterally terminate the treaty by giving notice prior to the treaties' expiration (often requiring such notice one year ahead of the renewal).

An emerging tactic is to request termination of the treaty with the intention of renegotiating a new treaty with the same state party. The approach is staggered so that it takes account of the various lock-in provisions. If we look closer at the states that have withdrawn from ICSID, we find that two of them have terminated or are in the process of terminating a very significant number of their BITs; Bolivia has terminated 11 and 10 remain in force, ${ }^{32}$ and Ecuador has terminated or decided to terminate 22 and four will remain in force. ${ }^{33}$ Arguably, these two states might qualify as 'absolute opponents' to the regime. The same could arguably be the case for Brazil, which has signed 20 BITs of which none have entered into force. ${ }^{34}$ Brazil published a model BIT in 2015 and signed six new BITs the same year, none of which include ISDS. Hence, Brazil could be classified as an absolute opponent to ISDS, but not to IIAs in general. Venezuela has not pursued any policy of denouncing its BITs (except its BIT with

\footnotetext{
${ }^{31}$ Kathryn Gordon \& Joachim Pohl, 'Investment Treaties over Time: Treaty Practice and Interpretation in a Changing World', OECD Working Papers on International Investment (Paris: OECD Publishing, 2015), 19.

${ }^{32}$ Bolivia has unilaterally terminated its BITs with Argentina (2014), Austria (2013), the Belgium-Luxembourg Economic Union (2014), Denmark (2014), France (2013), Germany (2013), the Netherlands (2009), Spain (2012), Sweden (2013), and the United States (US) (2012). It has not signed any new BITs or other IIAs since 2004. UNCTAD supra $\mathrm{n} 1$ as of 16 May 2017.

${ }^{33}$ Ecuador has terminated its BITs with Cuba (2008), Dominican Republic (2008), El Salvador (2008), Finland (2010), Guatemala (2008), Honduras (2008), Nicaragua (2008), Paraguay (2008), Romania (2008), and Uruguay (2008). It has not signed any new BITs or other IIAs with ISDS clauses since 2002. UNCTAD supra $\mathrm{n} 1$ as of 16 May 2017. Parliamentary decisions of 3 May 2017 decided that Ecuador shall denounce its BITs with Argentina, Bolivia, Canada, Chile, China, Italy, the Netherlands, Peru, Spain, Switzerland, the US, and Venezuela. See El Telégrafo, 'La Asamblea Denuncia 12 Tratados Bilaterales de Inversión’ (3 May 2017). This decision follows decisions by the Constitutional Court regarding the constitutionality of ISDS clauses in BITs, see Alexander Avtgis, 'Rethinking Article 422: A Retrospective on Ecuador's 2008 Constitutional ISDS Recalibration' (2016) 2(2) Indiana Journal of Constitutional Design, at 8-11.

${ }^{34}$ The new BITs were signed with Angola, Chile, Colombia, Malawi, Mexico, and Mozambique. UNCTAD supra $\mathrm{n} 1$ as of 16 May 2017. An explanation could be that these BITs were signed by Brazil as an emerging capital exporter. See also Welsh et al. supra n 19; Yoram Haftel \& Alexander Thompson, 'Delayed Ratification: The Domestic Fate of Bilateral Investment Treaties’ (2013) 67 International Organization 355-387.
} 
the Netherlands), and while it seems to have wished to pursue a strategy of material exit, the result has been a tactic of voice, an expression of displeasure. ${ }^{35}$

\subsection{Hybrid tactics}

A second group of states have adopted an approach that combines different exit and voice tactics, which may be effective in balancing enhanced sovereignty with the need to maintain a reputation for a positive investment climate. Such initiatives could include termination of BITs combined with the aim of renegotiating ISDS provisions or substantive clauses that are regarded as particularly controversial. Whether other states are always likely to be more sympathetic to such approaches than to unilateral termination is hard to say. States belonging to the group of compliers could in some cases prefer that other states remain within the regime, and accept the renegotiation of the IIA. However, other compliers may oppose renegotiation because it could set a precedent and lead to further calls for systemic reform.

Based on a review of states that have terminated a significant number of their treaties, either unilaterally or by mutual consent, we may possibly consider the Czech Republic, India, Indonesia, Italy and South Africa in this category. ${ }^{36}$ In addition, some states have engaged in systematic renegotiation of their IIAs. Based on theoretical considerations and anecdotal evidence, Haftel and Thompson hypothesize that 'states renegotiate when they acquire new information about the legal and political consequences of their treaty commitments, and that this learning occurs especially when states are involved in investment arbitration. ${ }^{37}$ Based on their findings, we take as a starting point that Romania, the Czech Republic, Germany, China, Egypt, Bulgaria, Morocco, Slovakia, and Finland can be regarded as significant renegotiators

\footnotetext{
${ }^{35}$ Venezuela has only terminated its BIT with the Netherlands (2008) and 27 BITs remain in force. UNCTAD supra $\mathrm{n} 1$ as of 16 May 2017.

${ }^{36}$ The Czech Republic has by mutual consent terminated its BITs with Denmark (2009), Estonia (2011), Ireland (2011), Italy (2009), Malta (2010), Slovakia (2004), and Slovenia (2009) - 77 BITs remain in force. India has unilaterally terminated its BITs with Argentina (2013), Australia (2017), Austria (2017), Hungary (2017), Indonesia (2016), Italy (2017), the Netherlands (2016) and Oman (2017) - 66 BITs remain in force. Indonesia has unilaterally (except for Argentina) terminated its BITs with Argentina (2016), Bulgaria (2015), Cambodia (2016), China (2015), Egypt (2014), France (2015), Hungary (2016), India (2016), Italy (2015), Lao PDR (2015), Malaysia (2015), the Netherlands (2015), Norway (2004), Pakistan (2016), Romania (2016), Singapore (2016), Slovakia (2015), Spain (2016), Switzerland (2016), Turkey (2016), and Viet Nam (2016) - 27 BITs remain in force. Italy has terminated its BITs with Bulgaria (2010, by consent), Croatia (2013), Czech Republic (2009, by consent), Estonia (2009, by consent), Hungary (2008, by consent), India (2017), Indonesia (2015), Latvia (2009, by consent), Poland (2013, by consent), Romania (2010, by consent), Slovakia (2012, by consent), Slovenia (2009, by consent), Uganda (2014), and Ukraine (2012, by consent) - 76 BITs remain in force. Italy also withdrew from the ECT (2014, effective 2016). South Africa has unilaterally terminated its BITs with Austria (2014), the Belgium-Luxembourg Economic Union (2013), Denmark (2014), France (2014), Germany (2014), the Netherlands (2014), Spain (2013), Switzerland (2014), and the United Kingdom (UK) (2014) - 14 BITs remain in force. Moreover, a significant number of treaties that these states have signed have not entered into force (Czech Republic - four; India - 10; Italy - 12; South Africa - 26), UNCTAD supra n 1 as of 16 May 2017. See also Haftel \& Thompson supra n 31.

${ }^{37}$ Yoram Haftel \& Alexander Thompson, 'When Do States Renegotiate Investment Agreements? The Impact of Arbitration’ (2017 forthcoming) The Review of International Organizations at 20 (pre-published version).
} 
with 10 or more renegotiated BITs each, the only overlap with our preliminary list being the Czech Republic. ${ }^{38}$ However, given that there are many alternative reasons why states may choose to renegotiate, we have exclude states that only or essentially have renegotiated old BITs that are ripe for renegotiation due to their limited investment protections (Bulgaria, ${ }^{39}$ Egypt, ${ }^{40}$ Germany ${ }^{41}$ and Morocco ${ }^{42}$ ) and states that have not been subject to significant ITAs (China $^{43}$ and Finland ${ }^{44}$ ). This means that we only add Romania and Slovakia to our list of states following hybrid tactics. ${ }^{45}$ What is common to all states in this hybrid category is that they have also been subject to ITA. ${ }^{46}$ This fits with the aggregative pattern of renegotiation tactics. According to Haftel and Thompson, there is only a $15 \%$ likelihood of renegotiation amongst states who have never experienced ITA; a figure that rises to $25 \%$ for states that have experienced three or more disputes. ${ }^{47}$

This hybrid approach is likely to become frequently adopted amongst those states who believe that IIAs are one-sided agreements that protect investors at the expense of a state's legitimate policy goals and its ability to regulate in the public interest. Prominent examples include

\footnotetext{
${ }^{38}$ Ibid at 10.

${ }^{39}$ According to our findings based on BITs that have been replaced by newer version BITs (a narrower definition of renegotiation than that of Haftel and Thompson, ibid) we find that Bulgaria has only renegotiated two BITs which first were signed during the period of 1984-88 and renegotiated versions were signed in 199799. UNCTAD supra $\mathrm{n} 1$ as of 16 May 2017.

${ }^{40}$ We find that all of Egypt's 13 renegotiated BITs were first signed during period of 1966-88 and renegotiated versions were signed between 1994-2010. UNCTAD supra n 1 as of 16 May 2017.

${ }^{41}$ We find that all of Germany's 18 renegotiated BITs were first signed during the period of 1959-83 and renegotiated versions were signed between1996-2010. UNCTAD supra n 1 as of May 2017.

${ }^{42}$ We find that all but two of Morocco's 12 renegotiated BITs were first signed during the period of 1961-1989 and renegotiated versions were signed in the period of 1996-2007. The status of the two remaining BITs is unclear as neither the original versions (signed in 1997 and 2001) nor the renegotiated versions (signed in 2001 and 2006) have entered into force. UNCTAD supra n 1 as of 16 May 2017.

${ }^{43}$ We only know of only two ITAs against China (supra n 9). We find a mixed picture for China concerning renegotiation: 13 of 15 renegotiated BITs were signed during the period of 1984-92, a period during which China included very limited ISDS clauses in its BITs. However, we do not have access to the treaty texts of all these treaties. The remaining two treaties were first signed with African states in 1997. UNCTAD supra $\mathrm{n}$ as of 16 May 2017.

${ }^{44}$ We know of no ITAs against Finland (supra n 9). We find a mixed picture for Finland concerning renegotiation: only four of nine renegotiated BITs were signed during the period of 1980-90 (three of which did not include ISDS clauses) and new versions were signed in the period of 1996-2004. The remaining five BITs were first signed between 1992-96 and renegotiated versions were signed between 2004-08, UNCTAD supra n 1 as of 16 May 2017.

${ }^{45}$ We find a mixed picture for Romania; seven out of 12 renegotiated BITs originated in the period of 1976-82 and renegotiated versions of these were signed between 1994-96. Two of the remaining BITs also seem to have been renegotiated at least partly due to weak protection of investors' rights (BITs with Korea and Turkey). The remaining three seem to have been renegotiated for other reasons (BITs with Canada, Greece and Kazakhstan). All the four renegotiated treaties of Slovakia were originally signed between1990-2000 and renegotiated versions were signed between 2002-2010. UNCTAD supra n 1 as of 16 May 2017.

${ }^{46}$ Our PITAD database (supra n 9) reveals the following number of disputes filed per state: Czech Republic (35), India (21), Indonesia (8), Italy (8), Romania (13), Slovakia (14) and South Africa (1). Only a minority of these disputes are ICSID arbitrations (32\% or 32 out of 100 disputes).

${ }^{47}$ Haftel \& Thompson supra n 36 at 17.
} 
Indonesia's notification that it intends to terminate all of its existing BITs with the goal of renegotiating new BITs with many (if not all) of its previous treaty partners, ${ }^{48}$ the Czech Republic which has actively terminated and renegotiated a high number of treaties out of public policy and other concerns, ${ }^{49}$ and South Africa whose new policy towards IIAs was triggered by the case of Foresti v. South Africa, which challenged its affirmative action legislation. ${ }^{50}$ In 2007, South Africa placed a moratorium on the negotiation of any new IIAs and conducted a full and comprehensive review of its IIA policy. Following the conclusion of the review in 2010, South Africa announced that it would refrain from entering into BITs unless there were compelling reasons for such a course of action and terminate existing BITs and offer renegotiation on the basis of a new model agreement. ${ }^{51}$

A materially different but symbolically similar strategy has been pursued by Australia. The Gillard government announced in 2011 that no future IIA with Australia would include ISDS provisions. $^{52}$ Subsequently, ITA provisions in IIAs have generally had a limited scope. ${ }^{53}$ However, after a change of government, Australia did sign and ratify an FTA with Korea that included strong ISDS provisions in 2014. It is therefore not clear that Australia could be added to our list of states with hybrid tactics.

\subsection{Systemic voice}

A final approach is a more indirect or step-by-step move towards 'balanced' IIAs. As noted above, there is a recent emergence of initiatives to renegotiate IIAs. These tactics generally form part of a hybrid strategy and thus it is rare to find states outside this category pursuing this goal. Moreover, clear instances of systemic political delegitimisation of IIAs are hard to identify beyond states’ attempts at termination of the ICSID Convention.

However, the adoption of a 'new generation' of model treaties over the past 10 years is a signal from some key states that IIAs are in need of reform. These states form a category that

\footnotetext{
${ }^{48}$ Leon Trakman \& Kunal Sharma, 'Indonesia's Termination of the Nethelrands-Indonesia BIT: Broader Implications in the Asia-Pacific' (Kluwer Arbitration Blog, 1 September 2014).

${ }^{49}$ Tomáš Fecák, 'Czech Experience with Bilateral Investment Treaties: Somewhat Bitter Taste of Investment Protection’ (2011) 2 Czech Yearbook of Public \& Private International Law 233-267.

${ }^{50}$ Piero Foresti, Laura de Carli \& Others v. The Republic of South Africa, ICSID Case No. ARB(AF)/07/01, discontinued 4 August 2010.

${ }^{51}$ The Cabinet based their decision on the DTI, Bilateral Investment Treaty Policy Framework Review, Pretoria, South Africa, June 2009.

52 Jürgen Kurtz, 'Australia's Rejection of Investor-State Arbitration: Causation, Omission and Implication', ICSID Review (2012) 27 (1): 65-86. ${ }^{53}$ See the investment chapter in the Australia - China Free Trade Agreement (2015), the Agreement between Australia and Japan for an Economic Partnership (2014), the Malaysia Australia Free Trade Agreement (2012), and the Protocol on Investment to the New Zealand - Australia Closer Economic Relations Trade Agreement (2011). UNCTAD supra n 1 as of 16 May 2017.

${ }^{53}$ See the investment chapter in the Australia - China Free Trade Agreement (2015), the Agreement between Australia and Japan for an Economic Partnership (2014), the Malaysia - Australia Free Trade Agreement (2012), and the Protocol on Investment to the New Zealand - Australia Closer Economic Relations Trade Agreement (2011). UNCTAD supra n 1 as of 16 May 2017.
} 
seeks to use systemic voice tactics. ${ }^{54}$ In the early 2000s, the US sought to develop a third generation model BIT that reflected the fact that it had been the subject of a number of suits by Canadian corporations under the NAFTA. The 2004 model US BIT scaled back a number of foreign investor protections in favour of protecting the sovereign prerogatives of the state hosting the foreign investment. While the 2004 model and more recent 2012 model include robust ISDS provisions, these provisions have been more thoroughly refined and many of the substantive provisions have been revised (level of foreign investor protection reduced). Overall, the models seek to 'recalibrate the balance between the rights accorded investors and a nation's right to regulate in the public interest. ${ }^{55}$

It has been contended that the new restrictive US model treaty has been as influential as the earlier expansive version:

If the United States led the charge in favour of investor protections, it now appears to be leading the drive in the opposite direction. The 2004 U.S. Model BIT is at least twice as long as it once was - and as every lawyer knows, the length of a treaty is often inversely related to the rights that it accords. The 2004 U.S. Model BIT has now shrunk, sometimes dramatically, virtually every right originally accorded to foreign investors while at the same time increasing, sometimes vastly, the discretion accorded host states. ${ }^{56}$

The changes have been influential and are reflected in treaties negotiated by states as diverse as Canada, Mexico, India and China. ${ }^{57}$ The recently concluded Comprehensive Economic and Trade Agreement between Canada and the EU (CETA, 2014) is particularly important in this regard, as it signals the future direction of the EU and consequently of its Member States with regard to IIAs. The CETA follows the approach of the US and Canada in most respects. Gordon and Pohl find that while significant differences remain, there is a convergence towards the US and Canadian model treaties. ${ }^{58}$ We know of 53 states that have drafted model treaties, of which 48 have made them publicly available potentially with a view to influencing the drafting policy of other states. The most active producer of such models has been the US which published its fifth model in 2012. Thereafter follow Germany, Guatemala and Turkey which have drafted three editions, as well as Colombia, India, the Netherlands, Norway and the UK which have drafted second editions. Moreover, some states of particular interest have

\footnotetext{
${ }^{54}$ See Tarald Laudal Berge \& Øyvind Stiansen, 'Negotiating BITs with Models: The Power of Expertise’ (2016) PluriCourts Research Paper No. 16-13.

${ }^{55}$ Jose Alvarez, 'Contemporary International Law: An "Empire of Law" or the "Law of Empire"' (2009) 24(5) American University International Law Review 811-842 at 834.

${ }^{56}$ Alvarez supra n 5 at 235.

${ }^{57}$ Ibid, 237.

${ }^{58}$ Gordon \& Pohl supra n 30 at 37-38.
} 
joined in recent years, including Brazil (2015), the Czech Republic (2016) and Slovakia (2016). ${ }^{59}$

\subsection{Concluding remarks}

The above discussion reveals that a number of states have made some significant changes in their approach to IIAs which intentionally or otherwise have sought to weaken their commitments as principals. While the number is small and may seem geographically limited, there are signs that more and more states are revising their approach to IIAs. However, the reforms vary in their intention, strength, and significance. So far, there are only two states (Ecuador and Bolivia) that are seeking a full and clean exit from the international investment regime. Other states have displayed a willingness to rebuild the ship while it sails at sea: some strengthening foreign investor rights, including ISDS (e.g., China and Germany), while the majority of others are weakening foreign investor rights while still remaining part of the regime. These states have sought to renegotiate treaties directly or exclude or limit ISDS clauses in treaties (e.g., Indonesia, India, Poland, Romania, the Czech Republic, Slovakia, Morocco, Italy, Bulgaria, Egypt, and South Africa) or changed the terms of their model treaties or their future negotiating strategy (e.g., US, the EU, Canada, Norway, Russia and Australia). Interestingly, the latter may exert the strongest material and symbolic effects on the overall international investment regime, although it is dependent on how arbitrators respond to the new provisions and signals.

\section{States as litigants in investment treaty arbitration}

The role of the state as a litigant in international legal disputes is quite different from its role as principal. It is different because when a state is a litigant in an international dispute, much of its authority as a sovereign is limited. Once a state has consented to a treaty that includes ISDS, it largely defers its control to a third party adjudicator. This is a reversal of the classical model of international arbitration in which jurisdiction for a dispute was negotiated on a caseby-case basis. In the case of ISDS, the state has a reduced ability to ex post modify the terms upon which it had previously agreed to be bound. Once a dispute has been initiated, the state is limited in the types of tactics it can employ to influence the proceedings. We will be looking at the particular tactics that states do (and can) wield in defending against private parties’ investment treaty claims.

States are always on the respondent side of the dispute in ITA. With counterclaims being infrequently invoked, state respondents in ITA are primarily concerned with avoiding liability that could result in large damage awards. In the early days of ITA claims, the infrequency of disputes meant that states likely responded and participated in defending investment treaty claims with few specific tactics in mind. However, as the regime has grown, states have

\footnotetext{
${ }^{59}$ UNCTAD supra n 1 as of 16 May 2017. We have included the Norwegian model treaties even if none of the two versions have been formally adopted. The most recent version of the Turkish model (2016) is not (yet) publicly available.
} 
developed a variety of tactics in defending claims; especially those states that have had to defend against multiple claims (i.e., Argentina and Venezuela).

While there is little evidence that states are taking extreme measures such as refusing to participate in arbitral proceedings ${ }^{60}$ or directly influencing arbitrators, ${ }^{61}$ there is evidence that states are employing increasingly aggressive tactics in defending ITA claims. These include a number of procedural and legal tactics, such as: utilizing the domestic criminal system of the respondent state; claimant and witness intimidation; reinterpreting treaties after a dispute is filed; refusing or delaying enforcement of awards (including excessive use of the ICSID annulment process); using novel jurisdictional challenges; and employing various tactics for delaying proceedings or making them excessively costly (such as refusing claim consolidation, claim bifurcation, challenging arbitrators and partial, delayed or no compliance with procedural and substantive orders).

The high-stakes and serious nature of many ITA claims can lead to the employment of aggressive litigation tactics on both sides. In this chapter, we focus exclusively on shifting trends in litigation tactics employed by respondent states. In some cases, these essentially mirror tactics equally available to foreign investor claimants. Yet, the state's sovereign authority may equally be used to obstruct or unbalance arbitral proceedings initiated by private parties. We will therefore draw on particular examples where the tactics employed by respondent states in ITA can be only pursued by a state (i.e., where the state uses both its sovereign status and/or the apparatus of the state itself to gain a tactical advantage in a proceeding against a private litigant).

Extensive resort to 'strong' litigation tactics by (ab)using the state's sovereign position would place states as either 'absolute opponents' of or 'reluctant compliers' to the international investment regime. However, an excessive use of other obstructionist tactics may also, in some circumstances, place a state in this category. (Ab)use of such tactics may easily breach the 'equality of arms' principle. We are particularly concerned with litigation tactics that can be seen to deviate from this principle. Waelde states the issue as:

'Equality of arms' is a foundation principle of investment arbitration procedure. A government sued on the basis of an investment treaty, signed to encourage foreign

\footnotetext{
${ }^{60}$ Some of the early (mid-twentieth century) investment arbitrations involving contract-based claims were adjudicated without participation of the respondent state (see e.g., the Libyan hydrocarbon concession arbitrations of the 1970s). However, there is one recent example whereby the Russian Federation is refusing to participate in ITA proceedings brought by Ukrainian investors in Crimea under the Russia-Ukraine BIT. See Aeroport Belbek LLC and Mr. Igor Valerievich Kolomoisky v. The Russian Federation, PCA Case No. 2014-30, pending; PJSC CB PrivatBank and Finance Company Finilon LLC v. The Russian Federation, PCA Case No. 2015-21, pending; Everest Estate LLC and others v. The Russian Federation, PCA Case No. 2015-36, pending.

${ }^{61}$ There is an infamous (and fairly unique) example where Indonesian officials abducted an arbitrator upon arrival at Schiphol airport in the Netherlands in order to prevent him from attending hearings in the Hague to which he was a member of the tribunal. See 'Himpurna v Indonesia' (2000) 15 Mealey's Int'l Arb. Rep. (February); see also Stephen Schwebel 'Injunction of Arbitral Proceedings and Truncation of the Tribunal', (2006) 3(2) Transnational Dispute Management.
} 
and private investment by promising effective protection, should prosecute its case vigorously but within the framework of the principles of 'good faith' arbitration, the applicable arbitration rules, and with respect to 'equality of arms, 62

As the ITA caseload grows, we are increasingly able to identify litigation trends where sovereign deference to the 'equality of arms' principle is waning. We will look at three recent trends that represent strong litigation tactics in which the state (perhaps) most clearly abuses its role as sovereign: (i) criminal proceedings during disputes; (ii) (ab)using the dual role of states in ITA; and (iii) refusing to enforce or satisfy arbitral awards.

\subsection{Criminal proceedings during disputes}

The most significant and recent tactical shift in the way that respondent states are defending ITA claims is in the area of domestic judicial proceedings. It is of course reasonable and not unusual for respondent states to use their judiciary to enforce domestic law against foreign investors operating within their borders. What is relatively new is a tactic whereby the domestic judicial machinery is activated as a response to an ITA claim. This tactic is arguably (ab)used for three purposes: (i) to obstruct, delay, or interfere with the proceedings of the ITA; (ii) to (ab)use the domestic legal system to obtain evidence and information that can be used against the claimant in the arbitration proceedings; and (iii) to intimidate, scare or coerce the claimant and its witnesses after the ITA is initiated. All three of these tactics are within the purview of the respondent host state to initiate, but can be seen as troubling where they have disguised objectives or can be seen as bad faith maneuvers in order to gain tactical advantage in a pending arbitration.

To highlight how states have used this tactic in recent cases, a number of pertinent examples are provided. In Border Timbers v. Zimbabwe and Von Pezold v. Zimbabwe, ${ }^{63}$ a group of Dutch and Swiss farm owners in Zimbabwe claimed that their farms were unlawfully expropriated. During the course of the proceedings, the claimants received a letter from Zimbabwe's attorney general demanding that they disclose certain documents in connection with the arbitration; and that if they refused, Zimbabwe would institute domestic criminal proceedings. ${ }^{64}$ In a procedural order dated 13 June 2012, the president of the tribunal directed

\footnotetext{
${ }^{62}$ Thomas Waelde, '’Equality of Arms' in Investment Arbitration: Procedural Challenges' in Katia YannacaSmall (ed) Arbitration Under International Investment Agreements: A Guide to the Key Issues (Oxford: Oxford University Press, 2008), 167.

${ }^{63}$ Border Timbers Limited, Timber Products International (Private) Limited and Hangani Development Co. (Private) Limited v. Republic of Zimbabwe (Border Timbers), ICSID Case No. ARB/10/25, Award, 28 July 2015; Bernhard von Pezold and Others v. Republic of Zimbabwe (Von Pezold), ICSID Case No. ARB/10/15, Award, 28 July 2015.

${ }^{64}$ Border Timbers, Directions Concerning Claimants’ Application for Provisional Measures of 12 June 2012, 13 June 2012; Von Pezold, Directions Concerning Claimants’ Application for Provisional Measures of 12 June 2012, 13 June 2012.
} 
Zimbabwe to cease pursuit of the demands. ${ }^{65} \mathrm{~A}$ year later the claimants requested urgent injunctive relief in relation to a number of threatening altercations on the claimant's farm to which the local police refused to provide assistance. In a procedural order refusing to grant the claimant's relief, the tribunal noted "that the Claimants continue to 'feel intimidated' by the threats made against their staff and that this intimidation is 'heightened by the fact that the Police will not act", ${ }^{66}$

In Quiborax v. Bolivia, ${ }^{67}$ the claimant brought a claim for compensation against Bolivia for unilaterally revoking several mining concessions. Almost three years into the arbitration, Bolivia initiated criminal proceedings against the main shareholder of Quiborax for allegedly forging documents. ${ }^{68}$ The effect was to limit the claimant's ability to access important documents relevant to the arbitration (they were seized by the state in relation to the domestic criminal proceedings); and that "the criminal proceedings are aggravating the dispute because they put intolerable pressure on them to abandon their claim and are thus aimed at avoiding the resolution of the dispute" ${ }^{69}$ Interestingly, there is evidence that the initiation of the criminal proceedings was designed as part of a larger defense strategy Bolivia developed specifically for this arbitration. ${ }^{70}$

In that same decision, the tribunal ultimately ordered Bolivia to suspend all pending criminal proceedings against the claimants and their witnesses pending the outcome of the arbitration. ${ }^{71}$ Given the close connection of these criminal proceedings with the arbitration, the tribunal was concerned that the respondent state's domestic actions could 'jeopardize the procedural integrity of this arbitration'. ${ }^{72}$ The claimant alleged that these criminal proceedings also served to reduce the willingness of witnesses to participate in the arbitration for fear of reprisals. $^{73}$

\footnotetext{
${ }^{65}$ Border Timbers, Directions Concerning Claimants’ Application for Provisional Measures, 12 June 2012; Von Pezold, Directions Concerning Claimants’ Application for Provisional Measures, 12 June 2012.

${ }^{66}$ Border Timbers, Procedural Order No. 4, 16 March 2013; Von Pezold, Procedural Order No. 4, 16 March 2013.

${ }^{67}$ Quiborax S.A. and Non-Metallic Minerals S.A. v. Plurinational State of Bolivia (Quiborax), ICSID Case No. ARB/06/2, Award, 16 September 2015.

${ }^{68}$ Luke Peterson, 'Arbitrators order that (Bolivian) criminal proceedings be suspended', (Investment Arbitration Reporter, 9 April 2010).

${ }^{69}$ Quiborax, Decision on Provisional Measures 1 February 2010, para. III.132.

${ }^{70}$ Ibid., para. III.122. "[T] hat it cannot fail to note that these [criminal proceeding] actions were taken after an inter-ministerial committee specifically recommended in the 2004 Memo that Bolivia should try to find flaws in Claimants' mining concessions as a defense strategy for the ICSID arbitration. Seen jointly with the 2004 Memo, the corporate audit and the criminal proceedings appear to be part of a defense strategy adopted by Bolivia with respect to the ICSID arbitration.”

${ }^{71}$ Ibid., para. V.2

${ }^{72}$ Ibid., para. V.1.

${ }^{73}$ Peterson supra n 46.
} 
In Caratube v. Kazakhstan (Caratube II), ${ }^{74}$ claimants initiated new proceedings relating to a previous award, Caratube v. Kazakhstan (Caratube I), ${ }^{75}$ which concerned the unilateral termination of a hydrocarbon concession. In what appears to be an increasingly personal and highly charged dispute, the claimants sought injunctive relief in order to protect Devincci Hourani (one of the primary claimants in the case), his relatives and associates from investigations and harassment relating to their alleged involvement in a 2004 murder in Lebanon. According to the request, Kazakhstan had enjoined as a partie civile in criminal proceedings against Hourani in Lebanon for an alleged murder. ${ }^{76}$ While the tribunal denied the claimants' request for provisional measures, it 'found that the Claimants have shown a certain need for protection in this Arbitration' and that the request was not 'unreasonable under the circumstances'. ${ }^{77}$

In Hydro v. Albania, ${ }^{78}$ a group of Italian investors and their companies brought a claim alleging that the Albanian authorities had failed to honor prior commitments in relation to their electricity generation enterprises in Albania. After the arbitration was initiated, Albania sought to have two of the claimants (Francesco Becchetti and Mauro De Renzis) extradited from the United Kingdom (UK) on allegations of money laundering and fraud. The claimants sought interim relief from the tribunal, requesting that the tribunal order Albania to desist from seeking the extradition of these two individuals from the UK. In its decision on provisional measures, the tribunal ordered Albania to cease the criminal and extradition proceedings pending the outcome of the arbitration. ${ }^{79}$

In Al Warraq v. Indonesia, ${ }^{80}$ a Saudi banker brought a claim that the nationalization of a bank to which he was a shareholder amounted to an unlawful expropriation. Indonesia defended the nationalization as an appropriate response to a foundering institution, and argued that the claimant was actually responsible for why the bank needed to be bailed out in the first place. In a domestic criminal proceeding that pre-dated the initiation of the arbitration, an Indonesian court found Al Warraq guilty in absentia of numerous financial crimes relating to his involvement in Bank Century. ${ }^{81}$ After the initiation of the arbitration, Al Warraq claimed

\footnotetext{
${ }^{74}$ Caratube International Oil Company LLP and Devincci Salah Hourani v. Republic of Kazakhstan (Caratube II), ICSID Case No. ARB/13/13, pending.

${ }^{75}$ Caratube International Oil Company LLP v. Republic of Kazakhstan (Caratube I), ICSID Case No. ARB/08/12, Award, 5 June 2012.

${ }^{76}$ Caratube II, Decision on the Claimants’ Request for Provisional Measures, 4 December 2014, para. 135.

${ }^{77}$ Ibid., para. 155.

${ }^{78}$ Hydro S.r.l. and others v. Republic of Albania (Hydro), ICSID Case No. ARB/15/28, pending.

${ }^{79}$ Hydro, Order on Provisional Measures, 3 March 2016.

${ }^{80}$ Hesham T. M. Al Warraq v. Republic of Indonesia (Al Warraq), UNCITRAL, Award, 15 December 2014.

${ }^{81}$ Luke Peterson, 'In Al Warraq v. Indonesia award, arbitrators devote bulk of their analysis to assessing investor's treatment in light of UN human rights treaty norms', (Investment Arbitration Reporter, 19 December 2014).
} 
that Indonesia attempted to derail the arbitration by freezing his assets and obtaining an Interpol Red Notice against him. ${ }^{82}$

Churchill v. Indonesia, ${ }^{83}$ concerns a claim that Indonesia had unilaterally, and without cause, terminated mining licenses in East Kalimantan. After the claim was brought, Indonesia initiated criminal proceedings against the claimants alleging that the mining licenses were procured through forged documents. ${ }^{84}$ The claimants contend that these criminal proceedings were initiated by Indonesia to “'cause maximum surprise and disruption,' and was a 'tactical move' directly connected to the arbitration”. ${ }^{85}$ In carrying out their criminal prosecution against the claimants domestically, Indonesia raided the offices of the claimants and confiscated numerous documents and computer hard drives that (as claimants allege) could be used as evidence against them in the pending ITA. ${ }^{86}$ While it is possible that the raid and the forgery proceedings are not being pursued in order to gain tactical advantage in the arbitration, there may be an good argument that Indonesia is using its sovereign authority in contravention of the 'equality of arms' principle or that its level of obstructionism places its actions in a more questionable category.

In a decision dated 15 February 2017, a tribunal in the case of Italba $v$. Uruguay ${ }^{87}$ refused to enjoin Uruguay from pursuing a criminal investigation against two of the claimant's witnesses in the case. ${ }^{88}$ Uruguay initiated the investigation on the basis that certain documents submitted to the tribunal by these witnesses were not authentic. Claimants in the case alleged that Uruguay was abusing its position as a sovereign in the case for the sole purpose of frustrating the arbitral proceedings.

The final example is slightly different from the previous. It deals with threats related to the potential initiation of an investment treaty claim. In Bozbey v. Turkmenistan, ${ }^{89}$ a Turkish businessman brought a claim relating to investments made in the agricultural sector in the 1990s. Bozbey alleged that "he was caught up in a wave of anti-Turkish sentiment in Turkmenistan, culminating in his imprisonment and mistreatment after he refused to comply with a request for a bribe issued by a local tax official”. ${ }^{90}$ After 18 months in prison, he returned to Turkey and initiated a claim with the United Nations Human Rights Committee

\footnotetext{
${ }^{82}$ Ibid.

${ }^{83}$ Churchill Mining and Planet Mining Pty Ltd, formerly ARB/12/40 v. Republic of Indonesia (Churchill), ICSID Case No. ARB/12/40 and 12/14, Award 6 December 2016.

${ }^{84}$ Jarrod Hepburn, 'Arbitrators again decline to order Indonesia to desist with criminal investigation into alleged forgery of mining license in Churchill \& Planet Mining case,' (Investment Arbitration Reporter, 30 December 2014).

${ }^{85}$ Ibid.

${ }^{86}$ Ibid.

${ }^{87}$ Italba Corporation v. Oriental Republic of Uruguay, ICSID Case No. ARB/16/9, pending.

${ }^{88}$ Italba, Decision on Claimant's Application for Provisional Measures and Temporary Relief, 15 February 2017.

${ }^{89}$ Farouk Bozbey v. Turkmenistan, UNCITRAL, discontinued 16 August 2013.

${ }^{90}$ Jarrod Hepburn and Luke Peterson, 'After claims of human rights violation are borne out, businessman pursues ad-hoc investment treaty arbitration against Turkmenistan (Investment Arbitration Reporter, 3 April 2013).
} 
(UNHRC). In that claim, he alleged that he was tortured while in prison and most importantly, he claimed that while in prison, officials "wanted him to sign legal documents ... to undertake that he would not make any complaints and apply to any international arbitration institution regarding his investments in the country". ${ }^{91}$ The UNHRC concluded that his conditions of detention constituted "a violation of his right to be treated with humanity and with respect for the inherent dignity of the human person under article 10, paragraph 1 , of the Covenant". 92 While Bozbey did ultimately bring an investment treaty claim, he had to abandon it before its conclusion because he could not meet the tribunal's request for an advance on costs.

As these cases demonstrate, it may be difficult to trace whether and how states use criminal proceedings in the context of ITAs. Moreover, we are frequently faced with situations where it is impossible or very difficult to determine who is at fault - the foreign investor, the state or both. The cases we have identified indicate varying types of domestic proceedings that states have brought against claimants after the initiation of the claim as well as the general reluctance of tribunals to order injunctive relief against such domestic proceedings. Tactically speaking, it appears that respondent states have a general degree of latitude in pursuing domestic criminal proceedings and that these proceedings may be effective in gaining an advantage over claimants. We may fear that as a consequence of such proceedings, states that suffer from corruption or lag behind in their implementation of 'rule of law' standards could be more successful than other states in ISDS. It is therefore essential that tribunals find ways to deal with such cases that do not place an excessive burden of proof on the claimant.

\section{2 (Ab)using the dual role of states}

The second category of litigation tactics pursued with increasing frequency by respondent states relate to a state's dual role as both party to the dispute with a foreign investor and party to the treaty upon which the dispute is based. This dynamic can create a scenario where the respondent state attempts to modify the provisions of a treaty in order to gain advantage in a dispute to which it is a party. Timing is crucial. As a party to a treaty, a state can always request the renegotiation (or interpretation of particular provisions) of the treaty with a treaty partner or partners. In a variety of ways, these new or subsequent treaties or agreements will bind adjudicators in future disputes. ${ }^{93}$ Renegotiation or modification becomes problematic when conducted after a particular dispute has been initiated. Below we provide a few

\footnotetext{
${ }^{91}$ Omar Faruk Bozbey v. Turkmenistan, Communication No. 1530/2006, U.N. Doc. CCPR/C/100/D/1530/2006 (2010), para. 5.6.

92 Ibid. at para. 7.3.

${ }^{93}$ The classic example is the interpretive statement issued by the Free Trade Commission (FTC) under the North American Free Trade Agreement (NAFTA). After arbitrations brought under NAFTA chapter 11 where treaty parties were dissatisfied with interpretations of the FET standard in the treaty, the FTC (comprised of the US, Canada, and Mexico) issued a binding interpretive statement restricting the interpretation of the FET standard to the customary international law minimum standard of treatment. This statement has had the effect of constituting a subsequent agreement under international law and has bound future NAFTA tribunals.
} 
examples where respondent states have sought the assistance of the investor home state for the purpose of weakening the investor's position in the arbitration.

In Sanum v. Lao PDR, ${ }^{94}$ an investor from Macau brought a claim based on the China-Lao PDR BIT. At issue in the case was whether the BIT was intended to include protections for investors from Macau (the location of the foreign investor claimant). In its award on jurisdiction, the tribunal held that the BIT does cover the investor from Macau and that the tribunal does have jurisdiction over the claim. Despite agreement to settle the case in mid$2014,{ }^{95}$ the respondent state continued to pursue set-aside proceedings against the award on jurisdiction in Singapore (the seat of the arbitration); and in January 2015, the Singapore High Court issued a decision setting aside the jurisdictional award; ${ }^{96}$ but was ultimately overturned on Appeal. ${ }^{97}$ Nonetheless, the respondent state sought to set aside the award on the basis of two letters from the Chinese government (which were a response to a request from Lao PDR) stating that the China-Lao PDR BIT does not apply to Macau. What is striking, and troubling, in this case is that the respondent state used its position as a treaty party to alter the outcome of the dispute by changing the meaning of a treaty after a dispute (to which it was a party) had already been decided by an international tribunal.

In Ecuador v. US, ${ }^{98}$ one of very few state to state disputes based on a BIT, Ecuador argued that US refusal to issue an interpretive note or amendment to the US-Ecuador BIT on the scope of the 'access to justice' provision in that treaty was unlawful. This dispute arose out of an earlier investment treaty claim, Chevron v. Ecuador (Chevron I), ${ }^{99}$ where Ecuador was dissatisfied with the tribunal's interpretation of the 'access to justice' provision. Ecuador brought the case with the aim of binding future tribunals, including the tribunal in the ongoing dispute of Chevron v. Ecuador (Chevron II). ${ }^{100}$ While the state to state dispute was dismissed by the tribunal for lack of jurisdiction, if it had been successful it would have bound a tribunal to a restrictive interpretation of a treaty provision that would favor Ecuador in an ongoing case.

These cases indicate that states may find difficulty in making unilateral modification to its commitments under IIAs after a dispute has arisen. However, the first case study referenced

\footnotetext{
${ }^{94}$ Sanum Investments Limited v. Lao People's Democratic Republic, UNCITRAL, PCA Case No. 2013-13, Award on Jurisdiction, 13 December 2013.

${ }^{95}$ Sanum Investments Limited v. Lao People's Democratic Republic, UNCITRAL, PCA Case No. 2013-13, Settlement Award, 15 June 2014.

${ }^{96}$ Government of the Lao People's Democratic Republic v. Sanum Investments Ltd. [2015] SGHC 15, 20 January 2015.

${ }^{97}$ Sanum Investments Ltd. v. Government of the Lao People's Democratic Republic [2016] SGCA 57, 29 September 2016.

${ }^{98}$ Republic of Ecuador v. United States of America, UNCITRAL, PCA Case No. 2012-5, Award, 29 September 2012.

${ }^{99}$ Chevron Corporation (USA) \& Texaco Petroleum Company (USA) v. The Republic of Ecuador (Chevron I), UNCITRAL, PCA Case No. 34877, Award, 31 August 2011.

100 Chevron Corporation \& Texaco Petroleum Corporation v. The Republic of Ecuador (Chevron II), UNCITRAL, PCA Case No. 2009-23, pending.
} 
above does provide anecdotal evidence that some post-dispute interpretations of IIAs may be possible. Generally speaking though, rules of international law, according to which disputes shall be determined on the basis of the law applicable at the time of the event that triggered the disputes, would in most cases prevent abuse. In situations where one could argue for flexibility in the application of the general rules, it is likely that tribunals will require strong arguments for exemptions to be accepted.

\subsection{Refusing to enforce or satisfy arbitral awards}

The difficulty in compelling a state to satisfy an international arbitral award against it is a long-standing problem. ${ }^{101}$ What might be new or shifting is the means by which states are avoiding enforcement. One of the central reasons driving the negotiation of the ICSID Convention in the 1960s was precisely related to the problem of enforcement. Article 53 of the ICSID Convention attempted to resolve this problem by making ICSID arbitration awards directly enforceable against the state.

The direct enforceability of awards under the ICSID Convention was systemically challenged for the first time following Argentina's financial collapse in 2001. Argentina has been steadfast in refusing to enforce ICSID awards. The argument has been that despite reference to the direct enforceability of awards in the ICSID Convention, the Argentinian constitution requires that all payments out of the state treasury must first be authorized through a domestic court judgment. Given the high number of ICSID awards against Argentina in the past 10 years, this non-compliance has put considerable strain on the long-term viability of the regime overall. While Argentina has recently satisfied five of its outstanding awards through a negotiated settlement, a number of final awards remain unsatisfied. ${ }^{102}$

In addition to the Argentinian cases, Zimbabwe, ${ }^{103}$ Russia, ${ }^{104}$ Kyrgyzstan, ${ }^{105}$ Venezuela, ${ }^{106}$ and Thailand ${ }^{107}$ have all refused to comply with any awards rendered against them. ${ }^{108} \mathrm{In}$

${ }^{101}$ See 1958 Convention on the Recognition and Enforcement of Foreign Arbitral Awards (New York Convention), 330 UNTS 38; 21 UST 2517; 7 ILM 1046 (1968).

${ }^{102}$ Luke Peterson, 'After settling some awards, Argentina takes more fractious path in bond-holders case, with new bid to disqualify arbitrators', (Investment Arbitration Reporter, 20 December 2013); Luke Peterson, 'Argentina announces another settlement of unpaid BIT awards, once again at a discount', (Investment Arbitration Reporter, 15 May 2016).

${ }^{103}$ Bernardus Henricus Funnekotter and others v. Republic of Zimbabwe, ICSID Case No. ARB/05/6, Award, 22 April 2009.

${ }^{104}$ Hulley Enterprises Limited (Cyprus) v. The Russian Federation, UNCITRAL, PCA Case No. AA 226, Award, 18 July 2014; Yukos Universal Limited (Isle of Man) v. The Russian Federation, UNCITRAL, PCA Case No. AA 227, Award, 18 July 2014; Veteran Petroleum Limited (Cyprus) v. The Russian Federation, UNCITRAL, PCA Case No. AA 228, Award, 18 July 2014; Renta 4 S.V.S.A, Ahorro Corporación Emergentes F.I., Ahorro Corporación Eurofondo F.I., Rovime Inversiones SICAV S.A., Quasar de Valors SICAV S.A., Orgor de Valores SICAV S.A., GBI 9000 SICAV S.A. v. The Russian Federation, SCC, Case No. 24/2007, Award, 20 July 2012; RosInvest Co UK Ltd. v. The Russian Federation, SCC, Case No. V079/2005, Award, 12 September 2010; Mr. Franz Sedelmayer v. The Russian Federation, SCC, Award, 7 July 1998.

${ }^{105}$ Stans Energy v. Kyrgyz Republic, Moscow Chamber of Commerce and Industry (MCCI), Award, 30 April 2014; OKKV (OKKB) and others v. Kyrgyz Republic, MCCI, Award, 21 November 2013; Lee John Beck \& 
addition, there are a number of respondent states that have sought to delay or refuse enforcement in individual cases: Guatemala, ${ }^{109}$ Libya, ${ }^{110}$ Kazakhstan, ${ }^{111}$ Mexico ${ }^{112}$ and Romania. ${ }^{113}$ These states have a record of complying with some awards and rigorously fighting enforcement in others.

The above list of states includes none from North America and Western Europe. However, there is one case that illustrates that refusal to enforce awards may be relevant for such states as well. In Micula $v$. Romania, ${ }^{114}$ a group of foreign investors initiated a claim under the Sweden-Romania BIT alleging that Romania withdrew a number of incentives in breach of the BIT. The European Commission (EC) intervened as amicus curiae expressing doubts as to whether an ICSID award against Romania would be enforceable. Nonetheless, on 11 December 2013, the tribunal issued a final award against Romania in the amount of 250 million US dollars (USD). In April 2014, Romania initiated annulment proceedings, but ultimately failed in annulling the result. ${ }^{115}$ In May 2014, the EC formally enjoined Romania

Central Asian Development Corporation v. Kyrgyz Republic, MCCI, Award, 13 November 2014; Sistem Mühendislik Inşaat Sanayi ve Ticaret A.Ş. v. Kyrgyz Republic, ICSID Case No. ARB(AF)/06/1, Award, 9 September 2009; Petrobart Limited v. Kyrgyz Republic, SCC, Case No. 126/2003, Award, 29 March 2005.

${ }^{106}$ All treaty-based arbitration awards based on Chavez-era nationalizations have not been honored to date. See Tenaris S.A. and Talta-Trading e Marketing Sociedade Unipessoal Lda. v. Bolivarian Republic of Venezuela (Tenaris II), Award, 12 December 2016; Rusoro Mining Ltd. v. Bolivarian Republic of Venezuela, ICSID Case No. ARB(AF)/12/5, Award, 22 August 2016; Vestey Group Ltd. v. Bolivarian Republic of Venezuela, ICSID Case No. ARB/06/4, Award, 15 April 2016; Crystallex International Corp. v. Bolivarian Republic of Venezuela, ICSID Case No. ARB(AF)/11/2, Award, 14 April 2016; Tenaris S.A. and Talta-Trading e Marketing Sociedade Unipessoal Lda. v. Bolivarian Republic of Venezuela (Tenaris I), ICSID Case No. ARB/11/26, Award 29 January 2016; Tidewater Investment SRL and Tidewater Caribe C.A. v. Bolivarian Republic of Venezuela, ICSID Case No. ARB/10/5, Award 13 March 2015; OI European Group B.V. v. Bolivarian Republic of Venezuela, ICSID Case No. ARB/11/25, Award, 10 March 2015; Flughafen Zürich A.G. and Gestión e Ingeniería IDC S.A. v. Bolivarian Republic of Venezuela, ICSID Case No. ARB/10/19, Award, 18 November 2014; Venezuela Holdings B.V. v. Bolivarian Republic of Venezuela, ICSID Case No. ARB/07/27, Award, 9 October 2014; Gold Reserve Inc. v. Bolivarian Republic of Venezuela, ICSID Case No. ARB(AF)/09/1, Award, 22 September 2014; ${ }^{107}$ Walter Bau A.G. v. Kingdom of Thailand, UNCITRAL, Award, 1 July 2009.

108 The cases listed in this section are limited to treaty-based investment claims (and may not be exhaustive). In addition to the states listed, there are a few states that have not enforced contract-based investment claims or have not complied with settlement agreements. Primarily, these include: Lao PDR, the Dominican Republic, the Democratic Republic of Congo, Ukraine and Turkmenistan.

${ }^{109}$ Railroad Development Corporation v. Republic of Guatemala, ICSID Case No. ARB/07/23, Award, 29 June 2012.

${ }^{110}$ Mohamed Abdulmohsen Al-Kharafi and Sons Co. v. Libya, CRCICA, Award, 22 March 2013.

${ }^{111}$ Rumeli Telekom A.S. and Telsim Mobil Telekomunikasyon Hizmetleri A.S. v. Republic of Kazakhstan, ICSID Case No. ARB/05/16, Award, 29 July 2008.

${ }^{112}$ Cargill Incorporated v. United Mexican States, ICSID Case No. ARB(AF)/05/2, Award, 18 September 2009.

${ }^{113}$ Ioan Micula, Viorel Micula and others v. Romania (Micula), ICSID Case No. ARB/05/20, Award, 11 December 2013.

${ }^{114}$ Micula.

${ }^{115}$ Micula, Decision on Annulment, 26 February 2016. 
from satisfying the ICSID award. ${ }^{116}$ The EC claims that the ICSID award is compensation for incentives that Romania had to remove in order to join the EU. These incentives constituted illegal state aid under the EU; and therefore, as the EC argues, any payment of compensation for the withdrawal of such illegal state-aid (i.e. the ICSID award) would be considered illegal state aid itself and therefore unenforceable. ${ }^{117}$

\subsection{Concluding remarks}

While some tactics used by respondent states can be highly obstructionist in effect, many simply mirror those adopted by foreign investors. However, more recently, and directly related to the expansion of investment treaty arbitration, respondent states are also using their sovereign position to fight claims. It is also becoming apparent that the more experienced a state is in defending against investment treaty claims, the more sophisticated (and less deferential to its power as a state) it becomes in its litigation tactics. While some of these tactics will have both material and symbolic effects, it is the latter that are likely to have the most influence on the system. Certain tactics may not have many material consequences beyond the specific dispute; but collectively, the various tactics we have explored may have significant effect on the way that investment treaty arbitration is perceived. Potential litigants may think twice before bringing a case. And states may have a strong interest in making system watchers aware of the burden that these cases place on them.

Even more profound, however, is the increasing acceptability of respondent state litigation tactics that can be classified as abusing their position as sovereign. For a few states, such tactics are part of their overall strategy to oppose the international investment regime, perhaps qualifying as 'absolute opponents' who aim at exiting the regime. However, most states applying such tactics do so in an ad hoc manner, and should rather be classified as 'reluctant compliers.' Moreover, it remains unclear how the tribunals will respond to the increasingly strong litigation tactics employed by some states. Therefore, it is still too early to tell what impact litigation tactics will have on the international investment regime as such.

\section{Conclusion}

Considering the current field of international investment law, it is easy to forget the fact that states have voluntarily consented to being bound by the provisions of the IIAs and that they have voluntarily accepted that such obligations can be adjudicated and enforced through mandatory ISDS provisions. In that sense, all participating states start out as compliers to the IIAs to which they are parties.

\footnotetext{
${ }^{116}$ Letter from the European Commission 26 May 2014, as confirmed in: European Commission State Aid Investigation, State aid SA.38517(2014/C) (ex 2014/NN) - Romania Implementation of Arbitral award Micula v Romania of 11 December 2013, 1 October 2014.

${ }^{117}$ Ibid.
} 
This chapter has suggested that when states become dissatisfied with aspects of their IIAs, they may become 'reluctant compliers', 118 'principled opponents', ${ }^{119}$ and occasionally 'absolute opponents'; ${ }^{120}$ and it is these distinct choices that frame the type of tactics that a state chooses to pursue its aims. It should be noted however, that while there is a significant shift in the tactics that states are pursing to increase sovereign maneuverability, no state to date has completely exited from the international investment regime. As such, this means that the strategy employed to date fits within the general thesis of this volume: states continue to engage with - and be a participant in - an increasingly legalized international landscape while at the same time making adjustments that attempt to minimize the effects on their on sovereign discretion. However, we have shown that the existing web of IIAs has a high degree of 'stickiness' and that some states have faced significant delays in their efforts to exit or change their obligations. The regime is thus designed in a manner to constrain such state strategies. We have also suggested that certain tactics may be pursued through two principal avenues: states acting 'as principals' and states acting 'as litigants', and it is clear that states have the ability to modify and influence the international regimes to which they have consented.

It is possible also that these strategies have had some success. Elsewhere, Langford and Behn have analyzed whether the backlash has affected outcomes in investment arbitration. ${ }^{121}$ There was a clear and early drop in success ratios after the emergence of the legitimacy crisis discourse and success in jurisdictional claims has declined over time. The multivariate analysis finds that some of this drop could be attributed to the backlash. However, the recalibration in outcomes for investors should not necessarily be viewed with great alarm. Success rates are much higher for investor claimants than human rights claimants in international and regional adjudicative bodies.

Why are states employing these strategies? Their invocation of legitimacy concerns with IIAs and ISDS arguably has some basis and their tactics cannot be reduced to a kneejerk sovereignty or realist reflex: that states never intended to cede sovereignty and that treaty commitment constitutes a false positive. It is true that one of the main concerns that states express about IIAs is their potential to interfere with domestic policy and the ability of the state to regulate in the public interest, ${ }^{122}$ even if the IIAs manifest the states' sovereign ability

\footnotetext{
${ }^{118}$ Arguably, the following states could be considered to be in the process of becoming 'reluctant compliers', based on our findings above: Argentina, Bolivia, Indonesia, Kazakhstan, Kyrgyzstan, Russia, Thailand and Zimbabwe.

${ }^{119}$ Arguably, the following states could be considered to be in the process of becoming 'principled opponents', based on our findings above: Argentina, Australia, Bolivia, the Czech Republic, Ecuador, Indonesia, South Africa and Zimbabwe.

${ }^{120}$ States qualifying as both 'reluctant compliers' and 'principled opponents' may be classified as 'absolute opponents.' This could apply to Argentina, Bolivia, Indonesia and Zimbabwe.

${ }^{121}$ Malcolm Langford \& Daniel Behn, 'Managing Backlash: The Evolving Investment Treaty Arbitrator', (2017 forthcoming) European Journal of International Law (pre-published version).

${ }^{122}$ David Schneiderman, Constitutionalizing Economic Globalization: Investment Rules and Democracy's Promise (Cambridge: Cambridge University Press, 2008).
} 
to advance another public interest: the long-term policy goal of economic development through the promotion of foreign direct investment.

Figure 3: Claimant-Investor Success Ratios (by year) ${ }^{123}$

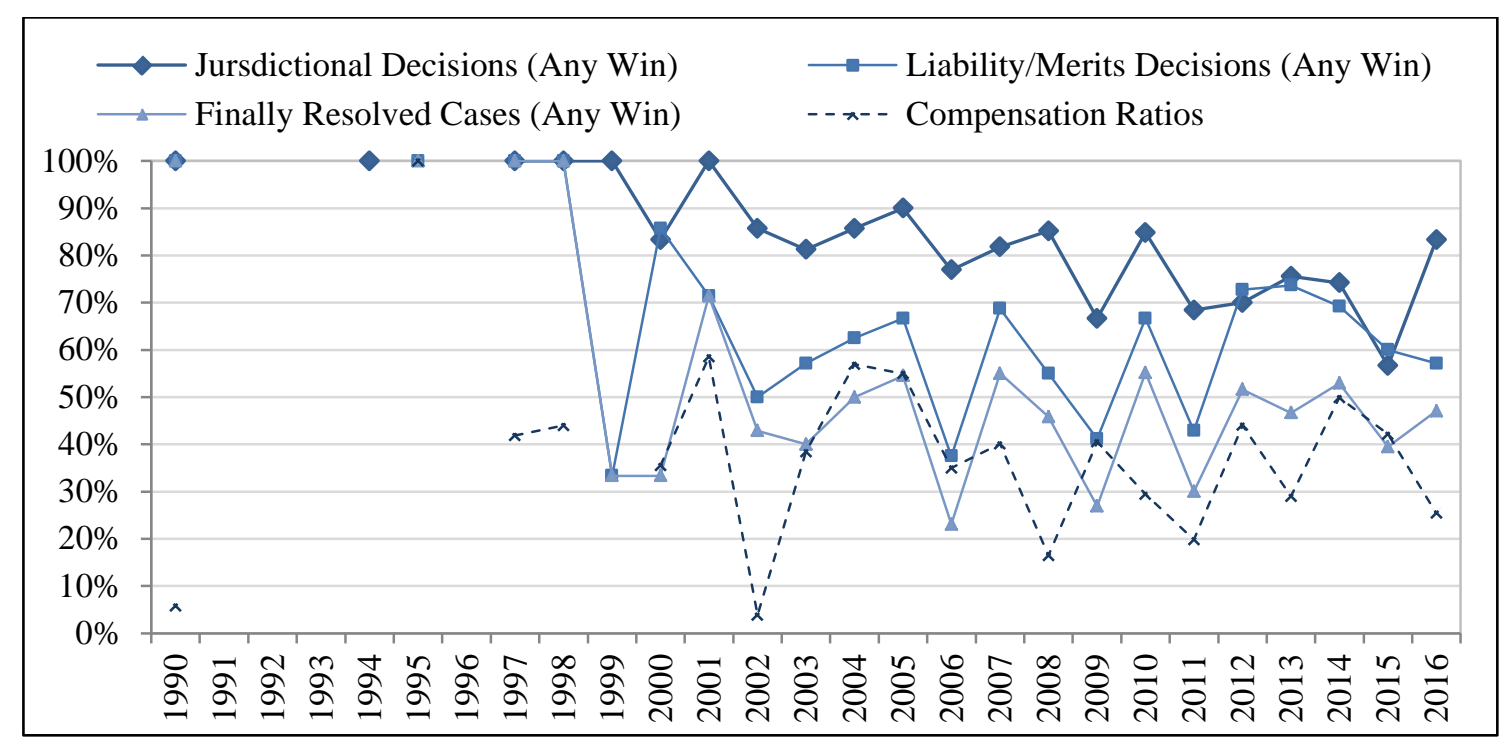

A more nuanced approach comes from rational choice theories which highlight the incentives and constraints for states in entering the regime. In the case of the international investment regime, states may balance: (i) making credible commitments in order to gain investment versus ensuring sufficient legal certainty over the potential costs of commitment; and (ii) the likelihood that they will be predominantly capital exporters or importers in the future. The existence of these two uncertainties means that states may need to ensure sufficient flexibility in regime design (or impose it later) to be able to respond if the basis for these trade-offs changes.

These calculations were also affected by certain background institutional, legal and political conditions that fostered ready commitment yet turned out to be highly fragile in practice. First, IIAs were an easy and attractive to sign. Only two states were required for an agreement, parliamentary assent was almost never required, and the whole event provided a perfect media event for visiting heads of state. Secondly, the pedigree of many of these treaties can be traced to a small number of model BITs developed by a few capital-exporting states in the 1980s and 1990s. Therefore, while each BIT should be viewed as a distinct and negotiated document between two states, the reality is that many BITs are very similar in the rights granted and - until the mid-1990s - do not appear to be the result of hard fought negotiation, but rather were often signed with little or no change from the capital-exporting states' model. Thirdly, the ideological climate at the domestic and international level has also shifted with a partial pushback in the last decade against the march of global neoliberalism. In the 1990s, UNCTAD recorded that $90 \%$ of regulatory reforms concerning investment inflows

\footnotetext{
${ }^{123}$ Extracted from Langford \& Behn, ibid.
} 
were pro-liberalization while that figure fell to less than $70 \%$ in 2009 - a third were restrictive.

Thus, one way of understanding the current backlash is that states are reassessing the actual and perceived utility of the treaties restricting their in this area of international law. ${ }^{124}$ As the practice of investment treaty arbitration develops, originally unanticipated consequences have become clearer. The importance of mandatory ISDS provisions in IIAs as a means to challenge policies that foreign investors view as detrimental to their interests has become clearer to many states. Moreover, there have been significant shifts in stocks and flows of foreign direct investment in recent decades changing the nature of capital exporter and importer states. ${ }^{125}$ The state - as the primary mover in consenting to international treaties can assert its sovereign authority by modifying or exiting regimes that are no longer perceived to be in that state's interests. Provided sufficient knowledge, whether IIAs remain a benefit to the state can be subjected to a cost-benefit analysis. For some states, it is clear that the costs do outweigh the benefits; and in coming to this realization they are likely to design strategies and tactics to remedy the imbalance. ${ }^{126}$ In this respect, be should be cautious about treating all international treaties as comparable, as is partly done in this volume. The logic of an investment treaty is partly different than a human rights treaty. The former is partly about fundamental protections but it is also deeply grounded in reciprocity and strategic economic policy choices.

In short, there are many reasons why we are seeing a backlash against the extensive web of IIAs that were signed during the last decades of the twentieth century. Commentators and negotiators talk about new 'generations' of treaties that seek to redefine the balance between rights of investors and policy freedom of states, as well as the role of ISDS. However, in this chapter, we do not comment here on whether states are morally right in engaging in this strategic behavior as principals. The legitimacy or justice of such state action is the subject of a burgeoning and heated literature. Nonetheless, we could find broader agreement that litigation tactics that involve states abusing their sovereign position are particularly problematic. The use of domestic criminal proceedings during disputes, refusals to comply with awards, and attempts to change treaties after a dispute is filed reveal not only an

\footnotetext{
${ }^{124}$ See e.g., Lavopa, Barreiros \& Bruno supra n 23.

${ }^{125}$ See World Investment Report 2015: Reforming International Investment Governance (Geneva: UNCTAD, 2015).

${ }^{126}$ At the time the vast majority of these treaties were signed, there was very little precedent on how the ISDS provisions would operate in practice: through the 1980s, there were only a handful of treaty-based arbitrations that had been initiated. While the modern investment treaty regime has its roots in the customary international law on the treatment of aliens, its specific development as a means of protecting and promoting foreign investment is a relatively new phenomenon that is frequently said to date from the signing of the first BIT between Pakistan and Germany in 1959. However, this BIT did not include any dispute settlement mechanism and instead could be viewed as a largely aspirational statement about the future cooperation between states on the promotion of foreign investment. It was not until 10 years later, in 1969, that the first BIT with ISDS was signed.
} 
infidelity by states to their treaty commitments but a failure to respect the international rule of law. 